\title{
Optimalisasi Sifat Reologi Hidrogel Kitosan-Hialuronat yang Ditaut- Silang dengan Glutaraldehida
}

\author{
Pajri Samsi Nasution, Muhamad Alif Hamimdal, Gustini Syahbirin, Budi Arifin* \\ Departemen Kimia, FMIPA, Institut Pertanian Bogor, Gedung Kimia Wing 1 Lantai 3, Jl. Tanjung, Kampus \\ IPB Dramaga, Bogor, Indonesia 16680 telp. (0251)8624567 \\ *Corresponding author \\ E-mail: budiarifin@yahoo.com
}

DOI: 10.20961/alchemy.15.1.22536.24-43

Received 31 December 2017, Accepted 21 January 2018, Published Online 01 March 2019

\begin{abstract}
ABSTRAK
Kitosan membentuk hidrogel polikationik dengan penambahan glutaraldehida sebagai penaut-silang. Penambahan hialuronat yang bersifat polianionik diharapkan akan meningkatkan sifat reologis hidrogel tersebut. Penelitian ini mengevaluasi pengaruh konsentrasi glutaraldehida dan hialuronat pada kekuatan gel, titik pecah, dan ketegaran, serta sifat pembengkakan dan pengerutan hidrogel kitosan, dan menentukan konsentrasi optimum keduanya melalui analisis data dengan perangkat lunak Modde $5^{\circledR}$. Hialuronat meningkatkan kekuatan gel, titik pecah, dan ketegaran hidrogel kitosan pada konsentrasi glutaraldehida yang rendah, tetapi berpengaruh sebaliknya pada konsentrasi glutaraldehida yang tinggi. Sejalan dengan itu, pembengkakan juga menjadi relatif tinggi, sedangkan pengerutan menjadi relatif rendah setelah penambahan hialuronat, tetapi hanya pada konsentrasi glutaraldehida yang rendah. Berdasarkan hasil ini, hialuronat diperkirakan mengisi ruang kosong di antara taut-silang imina yang terbentuk antara glutaraldehida dan kitosan. Pada konsentrasi glutaraldehida yang tinggi, taut-silang ini tidak menyisakan lagi ruang kosong bagi hialuronat. Sebaliknya, air sedikit demi sedikit akan terdesak keluar dari dalam hidrogel dan memicu pengerutan. Komposisi optimum diperoleh pada konsentrasi kitosan 2,0\% (b/v), hialuronat 0,3\% (v/v) dan glutaraldehida $1,4 \%(\mathrm{v} / \mathrm{v})$, yang memberikan kekuatan gel, titik pecah, ketegaran, pembengkakan dan pengerutan berturut-turut sebesar $678,4 \mathrm{~g} \mathrm{~cm}^{-2} ; 1,294 \mathrm{~cm} ; 5,033 \mathrm{~g} \mathrm{~cm}^{-1} ; 2,634 \mathrm{~g}$ dan $0,148 \mathrm{~g}$. Pengukuran sifat reologi hidrogel yang dibuat dengan komposisi optimum tersebut memberikan hasil yang lebih rendah $\left(190,7 \mathrm{~g} \mathrm{~cm}^{-2} ; 0,767 \mathrm{~cm} ; 1,675 \mathrm{~g} \mathrm{~cm}^{-1}\right)$ untuk tiga sifat reologi pertama, tetapi lebih tinggi $(2,844 \mathrm{~g}$ and $0,348 \mathrm{~g}$ ) untuk dua sifat berikutnya.
\end{abstract}

Kata kunci: kekuatan gel, kitosan, pembengkakan, titik pecah, taut-silang.

\begin{abstract}
Optimization of Rheological Property of Chitosan-Hyaluronate Hydrogel Crosslinked by Glutaraldehyde. Chitosan forms a polycationic hydrogel by addition of glutaraldehyde as a crosslinker. The addition of hyaluronate which is polyanionic is expected to improve the rheological properties of the hydrogel. This study evaluated the effects of glutaraldehyde and hyaluronate concentration on the gel strength, breakpoint, and rigidity of the chitosan hydrogel as well as the swelling and shrinking properties. This study determined the optimum concentration of both of glutaraldehyde and hyaluronate by data analysis using Modde $5^{\circledR}$ software. Hyaluronate increased the gel strength, breakpoint, and rigidity at a low glutaraldehyde concentration, but showed the opposite effects at high glutaraldehyde concentration. At a low concentration of glutaraldehyde, relatively high swelling and low shrinking
\end{abstract}


were revealed after hyaluronate addition. From these results, it was suggested that hyaluronate filled the empty spaces between the imine-crosslinks created by glutaraldehyde and chitosan. At high concentration of glutaraldehyde, the crosslinks became so extensive that no more space was left for hyaluronates. Otherwise, water would be squeezed out from the hydrogel and syneresis would happen. The optimum composition was obtained at $2.0 \%(\mathrm{w} / \mathrm{v})$ chitosan, $0.3 \%(\mathrm{v} / \mathrm{v})$ hyaluronate and $1.4 \%(\mathrm{v} / \mathrm{v})$ glutaraldehyde, which achieved the gel strength, breakpoint, rigidity, swelling and shrinking of $678.4 \mathrm{~g}$ $\mathrm{cm}^{-2}, 1.294 \mathrm{~cm}, 5.033 \mathrm{~g} \mathrm{~cm}^{-1}, 2.634 \mathrm{~g}$ and $0.148 \mathrm{~g}$, respectively. However, rheological property measurement of hydrogel synthesized by using the optimum composition gave lower results $(190.7 \mathrm{~g}$ $\left.\mathrm{cm}^{-2}, 0.767 \mathrm{~cm}, 1.675 \mathrm{~g} \mathrm{~cm}^{-1}\right)$ for the first three properties, but higher results $(2.844 \mathrm{~g}$ and $0.348 \mathrm{~g})$ for the latter two.

Keywords: breakpoint, chitosan, crosslink, gel strength, swelling.

\section{PENDAHULUAN}

Kitosan adalah suatu polisakarida linear turunan kitin, tersusun dari unit-unit monomer D-glukosamina dan $\mathrm{N}$-asetil-D-glukosamina, yang dihubungkan dengan ikatan glikosidik $\beta$-(1 $\rightarrow 4)$ (Montembault et al., 2005; Duarte et al., 2009). Berbeda dari kebanyakan polisakarida alami yang bersifat netral atau asam, kitosan bersifat basa karena memiliki banyak gugus amino pada tulang punggungnya (Mak and Sun, 2008). Pada pH di bawah 6,5, kitosan akan mengalami protonasi membentuk struktur polikationik (ArginSoysal et al., 2009).

Tautan-silang lazim dibentuk secara fisis atau kimiawi di antara rantai-rantai polimer kitosan untuk memperbaiki sifat-sifatnya seperti stabilitas dan durabilitas untuk keperluan pengantaran obat. Bahan penaut-silang seperti senyawa dialdehida umumnya digunakan untuk membentuk tautan-silang kimiawi, yang menghasilkan hidrogel kitosan atau jejaring polimer hibrida (HPN, hybrid polymer network), saling-tembus (IPN, interpenetrating polymer network), atau semi-IPN antara kitosan dan polimer lainnya (Ahmadi et al., 2015).

Glutaraldehida atau 1,5-pentanadial merupakan bahan penaut-silang yang banyak digunakan untuk membentuk tautan-silang kimiawi pada kitosan (Beppu et al., 2007), khususnya ketika suatu polimer lain ditambahkan pada kitosan untuk memodifikasi sifatsifatnya (Ahmadi et al., 2015). Sepasang gugus aldehida pada glutaraldehida akan bereaksi dengan sepasang gugus amino pada rantai kitosan yang berbeda dan membentuk ikatan imina. Ikatan imina ini stabil karena beresonansi dengan ikatan rangkap yang terbentuk di sampingnya (Monteiro Jr. and Airoldi, 1999).

Asam hialuronat juga merupakan polisakarida linear seperti halnya kitosan. Strukturnya berupa disakarida berulang dari asam D-glukuronat dan $\mathrm{N}$-asetilglukosamina yang dihubungkan berselang-seling dengan ikatan glikosidik $\beta-(1 \rightarrow 4)$ dan $\beta-(1 \rightarrow 3)$. Akan tetapi, berkebalikan dengan kitosan, pada $\mathrm{pH}$ fisiologis, molekul ini berbentuk garam 
polianionik yang lazim disebut hialuronat atau hialuronan (Mráček et al., 2008) dan merupakan komponen utama pada tulang rawan, cairan mata, dan cairan sendi (Nishinari and Takahashi, 2003).

Kombinasi struktur polikationik kitosan dan polianionik hialuronat telah dilaporkan membentuk kompleks polielektrolit (PEC) yang dapat menyerap air hingga 13 kali massanya pada pH 4 (Kim et al., 2003). Hidrogel hibrida kitosan-hialuronat ini juga berpotensi diaplikasikan sebagai perancah (scaffold) berpori-kecil untuk regenerasi pulpa gigi (Coimbra et al., 2011). Namun, penambahan hialuronat ke dalam hidrogel kitosan yang telah terbentuk dengan penambahan glutaraldehida belum pernah dilaporkan.

Sugita et al. telah melaporkan bahwa penambahan berbagai hidrokoloid, meliputi gom guar (Sugita et al., 2006), alginat (Sugita et al., 2007a), karboksimetilselulosa (Sugita et al., 2007b), dan gom xantan (Sugita et al., 2007c) mampu memperbaiki sifat reologi hidrogel kitosan yang meliputi kekuatan gel (gel strength), titik pecah (break point), ketegaran (rigidity), pembengkakan (swelling) dan pengerutan (shrinking). Penelitian ini bertujuan meneliti pengaruh terhadap sifat reologi penambahan hialuronat ke dalam hidrogel kitosan yang tertaut-silang oleh Glu. Penambahan hialuronat diperkirakan akan membentuk PEC yang kuat dengan gugus amonium bebas pada kitosan, sehingga akan mengisi secara efektif ruang kosong di antara jejaring taut-silang imina antara kitosan dan glutaraldehida. Hal ini diharapkan akan meningkatkan kekuatan gel, titik pecah, ketegaran dan pembengkakan, serta menurunkan pengerutan hidrogel kitosan.

\section{METODE PENELITIAN}

\section{Pencirian Kitosan dan Hialuronat}

Kitosan yang digunakan berasal dari cangkang kepiting, diperoleh dari PT Ajinomoto, sedangkan hialuronat dalam bentuk garam natrium didapat dari PT Bioland. Kadar air kitosan dan hialuronat ditentukan sebanyak 3 kali ulangan dengan water moisture tester Sartorius ${ }^{\circledR}$ di PT Arya Scientific. Sebanyak 0,500 g sampel ditimbang dalam alat tersebut kemudian alat dioperasikan pada suhu $105{ }^{\circ} \mathrm{C}$. Pemanasan akan berhenti jika massa contoh sudah konstan dan kadar air akan ditampilkan pada layar.

Derajat deasetilasi (DD) kitosan ditentukan dengan membandingkan nilai serapan inframerah gugus amida $\left(1655 \mathrm{~cm}^{-1}\right)$ dengan gugus hidroksil $\left(3450 \mathrm{~cm}^{-1}\right)$ (Khan et al., 2002). Kitin yang tidak terdeasetilasi menghasilkan nisbah $A_{1655} / A_{3450}=1,33$, maka derajat deasetilasi dihitung menggunakan persamaan (1): 


$$
D D=\left[1-\left(\frac{A_{1655}}{A_{3450}} \times \frac{1}{1,33}\right)\right] \times 100 \%
$$

Bobot molekul kitosan dan hialuronat ditentukan dengan metode viskometri Ostwald. Sekitar 0,1 g kitosan (bobot basah) ditimbang teliti lalu dilarutkan dalam $100 \mathrm{~mL}$ larutan $0,50 \mathrm{M}$ asam asetat. Sebanyak $10 \mathrm{~mL}$ larutan ini kemudian ditentukan waktu alirnya dalam viskometer ostwald sebanyak 3 kali ulangan. Pengukuran juga dilakukan untuk konsentrasi 0,$02 ; 0,04 ; 0,06$ dan $0,08 \%(\mathrm{~b} / \mathrm{v})$ larutan kitosan dalam asam asetat 0,50 M (Tarbojevich and Cosani, 1997). Densitas larutan kitosan dan pelarut ditentukan dengan piknometer. Metode yang sama digunakan untuk penentuan bobot molekul hialuronat, tetapi konsentrasi larutan hialuronat yang diukur waktu alirnya ialah 0,$1 ; 0,2 ; 0,3 ; 0,4 ; 1,0$ dan $10 \mathrm{~g} / \mathrm{L}$ dalam larutan 0,20 M natrium klorida (Kuo, 2006).

Persamaan (2) sampai (4) digunakan untuk menentukan viskositas:

$$
\begin{aligned}
& \text { Viskositas relatif: } \eta_{r}=\frac{\rho \eta}{\rho_{0} \eta_{0}} \cong \frac{t}{t_{0}} \\
& \text { Viskositas spesifik: } \eta_{s p}=\eta_{r}-1 \\
& \text { Viskositas intrinsik: }[\eta]=\left(\frac{\eta_{s p}}{c}\right)_{c \rightarrow 0}
\end{aligned}
$$

$\rho, \eta$, dan $t$ berturut-turut adalah densitas, viskositas, dan waktu alir larutan contoh, sementara $\rho_{0}, \eta_{0}$, dan $t_{0}$ berturut-turut ialah densitas, viskositas, dan waktu alir pelarut.

Persamaan (5) adalah bentuk linear dari persamaan (4). Dari persamaan ini, diperoleh nilai $[\eta]$ yang kemudian digunakan untuk mendapatkan bobot molekul $M$ dengan menggunakan persamaan (6):

$$
\begin{aligned}
& \ln \left(\frac{\eta_{s p}}{c}\right)=\ln [\eta]+K[\eta]^{2} c \\
& {[\eta]=K M^{a}}
\end{aligned}
$$

Nilai tetapan $K$ dan $a$ untuk kitosan menggunakan nilai untuk larutan dalam 0,5 M AcOH0,2 M NaOAc, yaitu 3,5 × 10-4 dan 0,76 (Tarbojevich and Cosani, 1997). Beberapa nilai tetapan $K$ dan $a$ telah dilaporkan untuk hialuronat. Penelitian ini menggunakan nilai untuk larutan dalam 0,2 M NaCl, yaitu berturut-turut 0,0228 dan 0,816 (Cleland, 1983).

\section{Penentuan Pelarut Kitosan dan Hialuronat}

Sebanyak 0,1 g hialuronat dilarutkan dalam 19,5 g pelarut. Pelarut yang digunakan terdiri atas larutan 2\% (v/v) asam asetat serta larutan 2, 10 dan 18\% (v/v) asam laktat. Larutan asam laktat diperoleh dengan mengencerkan larutan $90 \%$ (v/v) asam laktat teknis. Setelah itu, ditambahkan 0,4 g kitosan dan campuran diaduk dengan pengaduk bermagnet hingga larut sempurna membentuk larutan 0,5\% (b/v) hialuronat dan 2,0\% (b/v) kitosan. 
Larutan $18 \%(\mathrm{v} / \mathrm{v})$ asam laktat menghasilkan larutan kitosan-hialuronat yang paling homogen, maka dipilih sebagai pelarut dalam sintesis hidrogel.

\section{Penentuan Ragam Konsentrasi Kitosan dan Glutaraldehida}

Hidrogel kitosan dibuat dari 9 kombinasi larutan 1,0; 2,0 dan 3,0\% (b/v) kitosan dalam larutan $18 \%$ (v/v) asam laktat dengan larutan 0,5; 1,0 dan 4,0\% (v/v) glutaraldehida. Larutan glutaraldehida dibuat dengan mengencerkan larutan 25\% (v/v) glutaraldehida teknis. Berdasarkan kestabilan hidrogel yang dihasilkan dan waktu gelasi yang dibutuhkan, dipilih larutan 2,0\% (b/v) kitosan dengan ragam konsentrasi larutan 1,0; 2,0 dan 3,0\% (v/v) glutaraldehida untuk dioptimalisasi.

\section{Penentuan Ragam Konsentrasi Hialuronat}

Larutan 0,$5 ; 1,0$ dan $1,5 \%(\mathrm{~b} / \mathrm{v})$ hialuronat dalam larutan $18 \%(\mathrm{v} / \mathrm{v})$ asam laktat diukur viskositasnya dengan viskometer Brookfield LF di PT Arya Scientific. Sebanyak 50 g larutan dimasukkan ke dalam gelas piala $50 \mathrm{~mL}$, lalu batang pemutar (spindle) dicelupkan dan diputar dengan kecepatan $6 \mathrm{rpm}$. Viskositas akan muncul pada layar setelah nilainya tetap. Berdasarkan viskositas larutan yang dihasilkan, dipilih ragam konsentrasi 0,5 dan 1,0\% (v/v) hialuronat untuk dioptimalisasi.

\section{Sintesis Hidrogel untuk Optimalisasi}

Berdasarkan ragam konsentrasi yang telah didapatkan, sebanyak 0,1;0,2 dan 0,3 $\mathrm{g}$ hialuronat berturut-turut ditambahkan dengan 19,5; 19,4 dan 19,3 g larutan 18\% (v/v) asam laktat, lalu diaduk hingga homogen. Kitosan sebanyak 0,4 g [2,0\% (b/v)] kemudian ditambahkan ke dalam setiap larutan, dan diaduk lagi hingga homogen. Ke dalam larutan kitosan-hialuronat ini ditambahkan 2,0 g larutan $30 \%$ (b/v) $\mathrm{NaOH}$ hingga tercapai $\mathrm{pH} 4$, lalu ditambahkan $1 \mathrm{~mL}$ larutan glutaraldehida dan diaduk kembali hingga homogen. Larutan yang terbentuk didiamkan selama semalam agar membentuk gel. Ragam konsentrasi glutaraldehida ialah 1,$0 ; 2,0$ dan 3,0\% (v/v) maka diperoleh 9 kombinasi hidrogel yang dioptimalisasi.

\section{Pengukuran Sifat Reologi Hidrogel}

Kekuatan gel, titik pecah dan ketegaran diukur dengan menggunakan penganalisis tekstur Stevens Leatherhead Food Research Association (LFRA) di Pusat AntarUniversitas, IPB. Contoh gel dalam cetakan diletakkan dalam tabung plastik berukuran 50 $\mathrm{mL}$, lalu alat dioperasikan, dan suatu beban bermassa tertentu akan digerakkan turun dengan laju tertentu dari jarak tertentu hingga menekan gel tersebut. Beban ini kemudian akan menekan gel dan mengubah bentuknya hingga pada kedalaman tertentu sehingga gel akan pecah (Bourne, 2002). 
Uji pembengkakan dilakukan dengan merendam kira-kira 1,0 g gel dalam $30 \mathrm{~mL}$ larutan buffer asetat pH 4 selama 24 jam pada suhu kamar. Selama proses pembengkakan, wadah ditutup untuk mencegah larutan buffer menguap. Setelah 24 jam, gel ditimbang kembali untuk mengetahui massa air yang terserap (Wang et al., 2004).

Uji pengerutan dilakukan dengan merendam kira-kira 2,0 g gel dalam $30 \mathrm{~mL}$ larutan buffer fosfat $\mathrm{pH} 7$ selama 24 jam pada suhu $10{ }^{\circ} \mathrm{C}$. Setelah itu, gel ditimbang kembali untuk mengetahui massa air yang berdifusi keluar dari gel (Wang et al., 2004).

\section{Analisis Data}

Rancangan acak lengkap digunakan dengan konsentrasi hialuronat 0,$0 ; 0,5$; dan $1,0 \%$ (b/v) serta konsentrasi glutaraldehida 1,0;2,0; dan 3,0\% (v/v) sebagai peubah bebas. Setiap sifat reologi diukur sebanyak 6 kali dan dipilih 3 data yang menghasilkan simpangan baku terendah. Perangkat lunak Modde 5.0 ${ }^{\circledR}$ digunakan untuk menentukan kombinasi konsentrasi hialuronat dan glutaraldehida yang menghasilkan sifat reologi optimum yaitu kekuatan, titik pecah dan pembengkakan gel yang maksimum serta ketegaran dan pengerutan gel yang minimum. Pengaruh perubahan konsentrasi hialuronat dan glutaraldehida pada setiap sifat reologi juga ditentukan.

\section{HASIL DAN PEMBAHASAN}

\section{Ciri-ciri Kitosan dan Hialuronat}

Kitosan yang digunakan memiliki kadar air 11,6\%, derajat deasetilasi 88,5\% dan bobot molekul $750 \mathrm{kDa}$. Derajat deasetilasi yang diperoleh telah memenuhi kriteria kitosan niaga, yaitu minimum 70\%. Dibandingkan dengan beberapa laporan sebelumnya (Tabel 1), kitosan yang digunakan dalam penelitian ini memiliki derajat deasetilasi dan bobot molekul yang lebih tinggi.

Tabel 1. Konsentrasi larutan kitosan yang digunakan untuk membentuk hidrogel

\begin{tabular}{|c|c|c|c|c|}
\hline Hidrogel & $\begin{array}{l}\text { DD } \\
(\%)\end{array}$ & $\begin{array}{c}M_{r} \text { Kit } \\
(\mathbf{k D a})\end{array}$ & $\begin{array}{c}c_{\mathrm{Kit}} \\
{[\%(\mathrm{~b} / \mathrm{v})]}\end{array}$ & Rujukan \\
\hline $\begin{array}{l}\text { Kit-Glu- } \\
\text { GG/Alg/CMC/GX }\end{array}$ & 73,6 & 430 & 2,5 & $\begin{array}{c}\text { Sugita et al. } \\
(2006,2007 \mathrm{a}, 2007 \mathrm{~b}, 2007 \mathrm{c})\end{array}$ \\
\hline Kit-CMC & $90 \mathrm{a}$ & $460^{\mathrm{a}}$ & 2,0 & Shang et al. (2008a) \\
\hline Kit-Glu-Alg & 75,5 & $141^{\mathrm{b}}$ & $0,5-1,3$ & Tahtat et al. (2013) \\
\hline Kit-HA & N/A & $161^{\mathrm{c}}$ & 2,5 & Kaderli et al. (2015) \\
\hline Kit-Glu-HA & 88,5 & 750 & 2,0 & Hasil Penelitian \\
\hline
\end{tabular}


Hialuronat yang digunakan berkadar air 13,1\% dan berbobot molekul 633 kDa. Bobot molekul yang lebih tinggi digunakan oleh Kaderli et al. (2015), yaitu 1300-2200 kDa (diukur dengan kromatografi eksklusi). Sebaliknya, Manna et al. (2009) dan Holmes and Tabrizian (2013) menggunakan hialuronat dengan bobot molekul lebih rendah, yaitu berturut-turut $160 \mathrm{kDa}\left(\operatorname{Sigma}_{-A_{1}} \operatorname{drich}^{\circledR}\right)$ dan $74 \mathrm{kDa}\left(\right.$ Lifecore Biomedical $\left.{ }^{\circledR}\right)$.

Perbedaan bobot molekul kitosan dan hialuronat serta derajat deasetilasi kitosan akan berpengaruh pada kelarutan serta viskositas larutan yang dihasilkan. Pembentukan larutan yang homogen serta viskositas larutan yang sesuai akan menentukan keberhasilan pembentukan hidrogel kitosan-hialuronat. Oleh karena itu, konsentrasi kitosan dan hialuronat yang akan digunakan dalam tahap optimalisasi terlebih dahulu harus ditentukan dalam studi pendahuluan.

\section{Konsentrasi Kitosan, Glutaraldehida, dan Hialuronat untuk Optimalisasi Sintesis Hidrogel}

Tabel 1 menunjukkan bahwa hidrogel lazim dibuat dari larutan 2,0 atau 2,5\% (b/v) kitosan. Tahtat et al. (2013) menggunakan konsentrasi lebih rendah karena pada konsentrasi lebih tinggi, dihasilkan butiran hidrogel yang terlalu besar. Oleh karena itu, studi pendahuluan dilakukan dengan larutan 1,0; 2,0 dan 3,0\% (b/v) kitosan. Konsentrasi $1,0 \%(\mathrm{~b} / \mathrm{v})$ ternyata terlalu rendah. Tidak terbentuk hidrogel yang kokoh, sekalipun konsentrasi penaut-silang glutaraldehida dinaikkan hingga 4,0\% (v/v) (Tabel 2). Menaikkan konsentrasi kitosan ke 2,0\% (b/v) menghasilkan hidrogel yang stabil dalam waktu 20 jam dengan glutaraldehida 1,0\% (b/v). Meningkatkan lagi konsentrasi kitosan ke 3,0\% (b/v) hanya sedikit memperpendek waktu gelasi menjadi 15 jam, sementara tekstur hidrogel yang dihasilkan relatif sama. Oleh karena itu, dipilih konsentrasi 2,0\% (b/v) kitosan untuk optimalisasi sintesis hidrogel.

Studi pendahuluan ini juga meragamkan konsentrasi glutaraldehida menjadi 0,5; 1,0 dan 4,0\% (v/v). Akan tetapi, glutaraldehida dengan konsentrasi 0,5\% (v/v) tidak membentuk hidrogel. Konsentrasi tersebut agaknya terlalu rendah, sehingga tautan-silang yang terbentuk terlalu sedikit untuk dapat memerangkap air di dalam matriks polimer. Sebaliknya, dengan 4,0\% (v/v) glutaraldehida, hidrogel terbentuk sangat cepat dalam waktu 1,2 jam saja. Namun hidrogel tersebut tidak stabil dan mengerut seluruhnya dalam 7 hari. Struktur 3-dimensi yang sangat rapat karena tautan-silang yang masif diperkirakan mendesak air untuk sedikit demi sedikit menetes keluar dari matriks polimer. Hidrogel yang stabil dihasilkan dengan $1,0 \%(\mathrm{v} / \mathrm{v})$ glutaraldehida dari konsentrasi kitosan 2,0 dan 
3,0\% (b/v). Oleh karena itu, ragam konsentrasi glutaraldehida 1,0; 2,0 dan 3,0\% (v/v) dipilih untuk dioptimalisasi.

Tabel 2. Hasil studi pendahuluan pembentukan hidrogel kitosan dengan penaut-silang glutaraldehida

\begin{tabular}{ccccc}
\hline $\begin{array}{c}\boldsymbol{c}_{\text {Kit }} \\
{[\%(\mathbf{b} / \mathbf{v})]}\end{array}$ & $\begin{array}{c}\boldsymbol{c}_{\text {Glu }} \\
{[\%(\mathbf{v} / \mathbf{v})]}\end{array}$ & $\begin{array}{c}\text { Waktu } \\
\mathbf{G e l a s i}^{\mathbf{a}}\end{array}$ & Wujud & Keterangan \\
\hline 1,0 & 0,5 & $\mathrm{~N} / \mathrm{G}$ & Cair & - \\
& 1,0 & $\mathrm{~N} / \mathrm{G}$ & Cair & - \\
& 4,0 & $8 \mathrm{jam}$ & Kurang padat & Mengerut setelah 8 hari \\
2,0 & 0,5 & $\mathrm{~N} / \mathrm{G}$ & Cair & - \\
& 1,0 & $20 \mathrm{jam}$ & Padat & Stabil \\
& 4,0 & $1,2 \mathrm{jam}$ & Padat & Mengerut setelah 7 hari \\
3,0 & 0,5 & $\mathrm{~N} / \mathrm{G}$ & Cair & - \\
& 1,0 & $15 \mathrm{jam}$ & Padat & Stabil \\
& 4,0 & 1,2 jam & Padat & Mengerut setelah 7 hari \\
\hline
\end{tabular}

Keterangan: Kit $=$ kitosan, Glu $=$ glutaraldehida, N/G = tidak terjadi gelasi .

Larutan 0,$5 ; 1,0$ dan $1,5 \% \quad(\mathrm{~b} / \mathrm{v})$ hialuronat selanjutnya digunakan untuk menentukan ragam konsentrasi hialuronat yang akan diteliti. Gambar 1 menunjukkan viskositas larutan yang meningkat tajam dari konsentrasi 1,0 ke 1,5\% (b/v). Larutan yang terlalu kental akan sulit diaduk dan mudah membentuk gelembung saat diaduk, yang sulit untuk dihilangkan. Oleh karena itu, optimalisasi menggunakan konsentrasi hialuronat 0,5 dan $1,0 \%(b / v)$ bersama dengan hidrogel kitosan blangko (tanpa penambahan hialuronat).

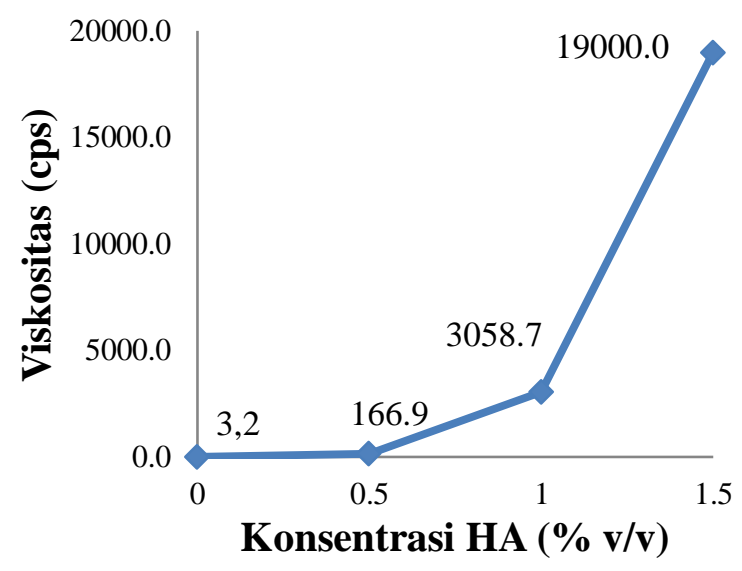

Gambar 1. Hubungan viskositas dengan konsentrasi larutan hialuronat

Asam laktat 18\% (v/v) digunakan untuk melarutkan kitosan dan hialuronat. Pelarut lainnya yang diujikan yaitu asam asetat 2\% (v/v) serta asam laktat 2 dan 10\% (v/v), semuanya melarutkan kitosan dengan baik tetapi terjadi agregasi setelah ditambahkan hialuronat. Agregat yang tidak larut dalam air ini diduga adalah PEC antara kitosan dan hialuronat (Gambar 2). Asam laktat dengan konsentrasi yang tinggi akan membentuk interaksi ionik yang dominan dengan gugus amino pada kitosan sehingga kitosan tidak 
membentuk PEC dengan hialuronat. Hasil ini sejalan dengan laporan Lindblad (2003) bahwa gugus amino pada kitosan dapat dicangkok oleh asam laktat tanpa bantuan katalis.

(a)
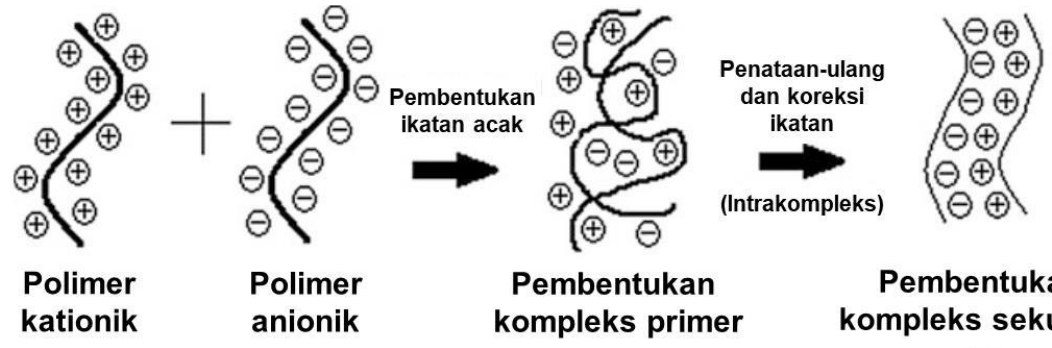

Pembentukan anionik kompleks primer kompleks sekunder
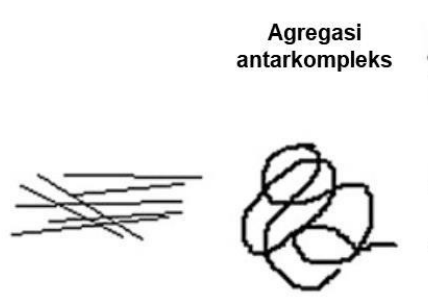

Belitan

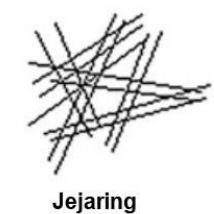

(b)

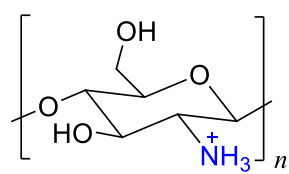

Fibril

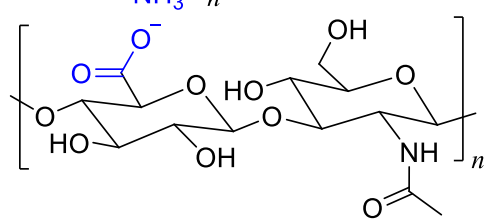

Gambar 2. Gambaran skematik pembentukan kompleks polielektrolit (PEC) (Buriuli and Verma, 2017) (a). Kitosan sebagai polimer kationik dan hialuronat sebagai polimer anionik dapat beragregasi membentuk PEC (b).

\section{Pengaruh Konsentrasi Glutaraldehida dan Hialuronat pada Sifat Reologi Hidrogel Kitosan-Hialuronat}

Hasil analisis ragam (ANOVA) (Tabel 3) menunjukkan pengaruh nyata konsentrasi hialuronat dan glutaraldehida pada taraf $\alpha=5 \%$ pada semua sifat reologi yang diukur. Selanjutnya pengaruh yang ditimbulkan pada setiap sifat reologi akan dikaji satu per satu. Kenaikan konsentrasi glutaraldehida dari 1,0 ke 2,0\% (v/v) meningkatkan kekuatan gel, tetapi jika dinaikkan lagi ke 3,0\% (v/v) kekuatan gel justru menurun (Gambar 3). Hasil penelitian Shang et al. (2008b) pada hidrogel kitosan-karboksimetil kitosan juga mendapatkan kekuatan pecah dan elastisitas yang optimum pada konsentrasi glutaraldehida yang rendah $[0,5-1,0 \%(\mathrm{v} / \mathrm{v})]$. Pada konsentrasi glutaraldehida yang rendah $[1,0 \%(\mathrm{v} / \mathrm{v})]$, semakin banyak hialuronat yang ditambahkan, kekuatan gel akan semakin meningkat. Hal sebaliknya teramati pada konsentrasi glutaraldehida yang lebih tinggi. 
Tabel 3. Hasil uji analisis keragaman (ANOVA) untuk sifat reologi hidrogel kitosanglutaraldehida-hialuronat

\begin{tabular}{llcc}
\hline \multicolumn{1}{c}{ Respons } & $\begin{array}{c}\text { Sumber } \\
\text { Keragaman }\end{array}$ & F & P \\
\hline Kekuatan gel & HA & 65,40 & $0,000^{*}$ \\
& Glu & 435,5 & $0,000^{*}$ \\
Titik pecah & Interaksi & 252,8 & $0,000^{*}$ \\
& HA & 296,4 & $0,000^{*}$ \\
& Glu & 125,6 & $0,000^{*}$ \\
Ketegaran & Interaksi & 46,92 & $0,000^{*}$ \\
& HA & 142,0 & $0,000^{*}$ \\
& Glu & 57,8 & $0,000^{*}$ \\
Pembengkakan & Interaksi & 192,7 & $0,000^{*}$ \\
& HA & 14,25 & $0,000^{*}$ \\
& Glu & 1144,7 & $0,000^{*}$ \\
Pengerutan & Interaksi & 124,9 & $0,000^{*}$ \\
& HA & 41,13 & $0,000^{*}$ \\
& Glu & 131,2 & $0,000^{*}$ \\
& Interaksi & 44,77 & $0,000^{*}$ \\
\hline
\end{tabular}

Keterangan: $\mathrm{F}=$ nilai uji $\mathrm{F}\left(\frac{\mathrm{KT}_{\text {keragaman }}}{\mathrm{KT}_{\text {galat }}}\right), \mathrm{P}=$ peluang menerima $H_{0}, \mathrm{HA}=$ hialuronat, Glu = glutaraldehida, $*$ = berpengaruh nyata pada $\alpha=0,05$.

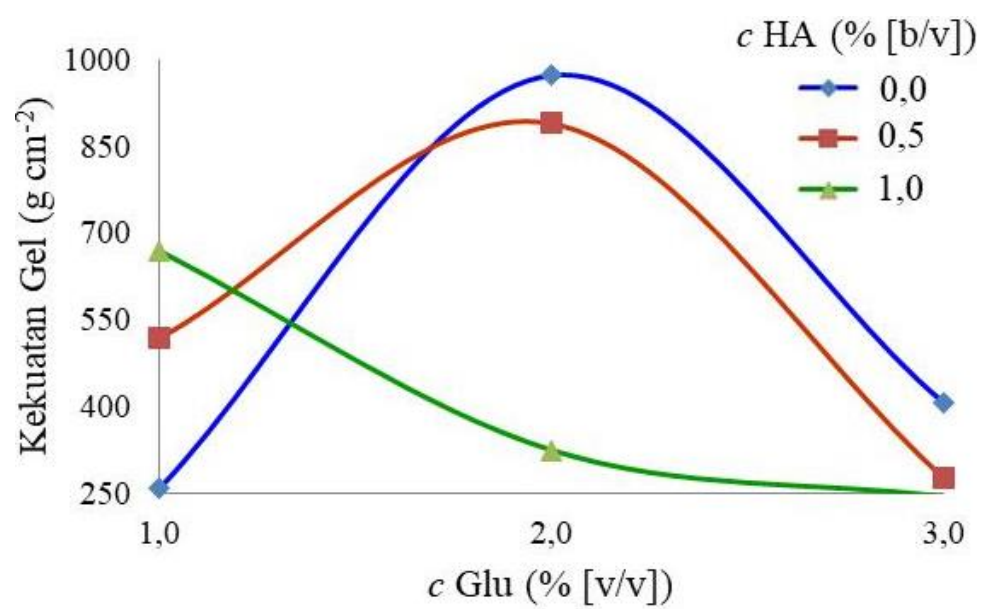

Gambar 3. Pengaruh konsentrasi glutaraldehida ( $c$ Glu) dan hialuronat ( $c \mathrm{HA}$ ) pada kekuatan gel kitosan-glutaraldehida-hialuronat.

Baik kitosan maupun glutaraldehida dapat membentuk tautan-silang dengan hialuronat (Gambar 4). Gugus karbonil pada glutaraldehida dapat membentuk hemiasetal dengan gugus hidroksil pada hialuronat (Tomihata and Ikada, 1997). Akan tetapi tautansilang kitosan dengan glutaraldehida lebih mudah terbentuk karena gugus amino lebih nukleofilik daripada gugus hidroksil sehingga lebih reaktif dalam mengadisi gugus karbonil. Hal ini dapat dilihat pada Gambar 3 pengaruh penambahan hialuronat pada kekuatan gel lebih kecil dibandingkan dengan penambahan glutaraldehida. Hialuronat diduga hanya mengisi ruang kosong di antara tautan-silang kitosan-glutaraldehida. 
Meskipun hal ini juga menstabilkan hidrogel, pengaruhnya jauh lebih kecil dibandingkan dengan stabilisasi karena pembentukan tautan-silang kovalen dengan glutaraldehida.

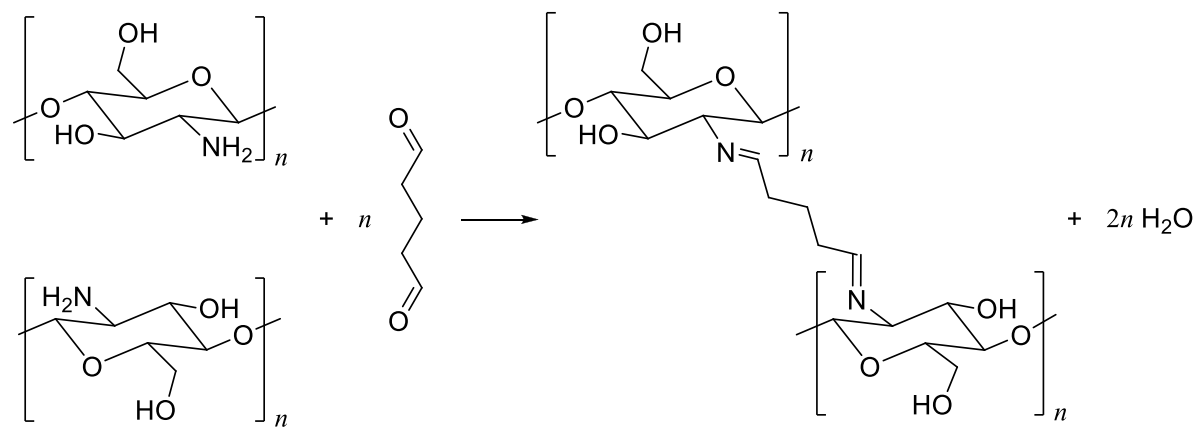

(a)

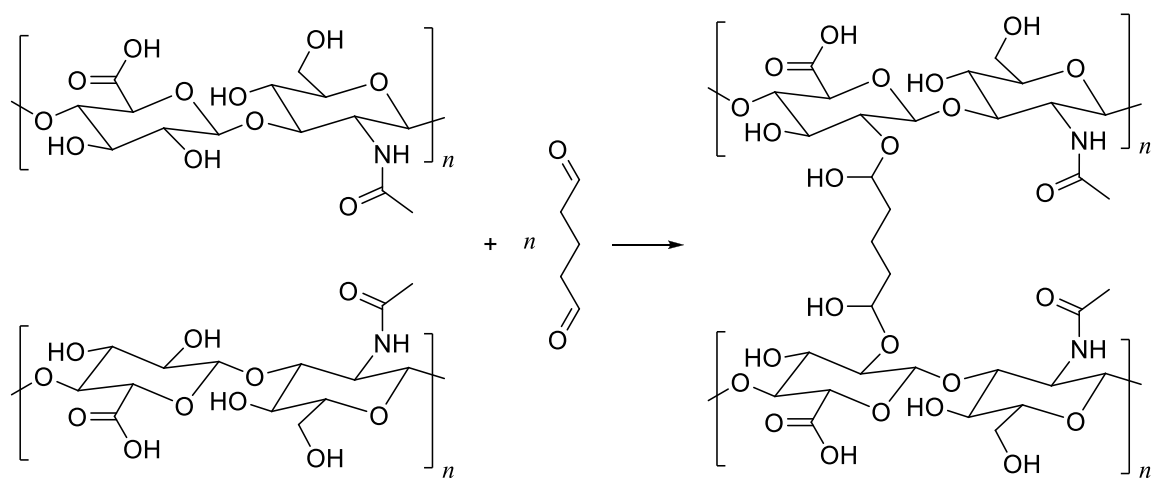

(b)

Gambar 4. Reaksi pembentukan tautan-silang antara 2 rantai kitosan (a) dan antara 2 rantai hialuronat (b) dengan bantuan glutaraldehida sebagai penaut-silang.

Kekuatan gel kitosan dengan 1,0\% (v/v) glutaraldehida tanpa hialuronat sebesar $258 \mathrm{~g} \mathrm{~cm}^{-2}$. Penambahan 0,50\% (b/v) hialuronat meningkatkan 2 kali lipat kekuatan gel menjadi $518 \mathrm{~g} \mathrm{~cm}^{-2}$, tetapi penambahan glutaraldehida menjadi 2,0\% (v/v) tanpa hialuronat meningkatkan kekuatan gel lebih tinggi lagi, hampir 4 kali lipat $\left(973 \mathrm{~g} \mathrm{~cm}^{-2}\right)$. Peningkatan konsentrasi hialuronat dari $0,5 \mathrm{ke} 1,0 \%$ (b/v) dengan konsentrasi glutaraldehida tetap 1,0\% (v/v) hanya meningkatkan kekuatan gel sebesar 30\% menjadi $669 \mathrm{~g} \mathrm{~cm}^{-2}$. Kenaikan yang lebih sedikit ini menunjukkan semakin terbatasnya ruang kosong di antara jejaring tautsilang hidrogel kitosan-glutaraldehida yang tersedia untuk diisi oleh hialuronat.

Kekuatan gel sebesar $973 \mathrm{~g} \mathrm{~cm}^{-2}$ dengan 2,0\% (v/v) glutaraldehida tanpa hialuronat merupakan nilai maksimum yang diperoleh dalam penelitian ini. Dengan konsentrasi glutaraldehida tersebut, penambahan $0,5 \%(\mathrm{~b} / \mathrm{v})$ hialuronat relatif tidak berpengaruh pada kekuatan gel $\left(889 \mathrm{~g} \mathrm{~cm}^{-2}\right)$. Penambahan 1,0\% (b/v) hialuronat justru menurunkan 3 kali lipat kekuatan gel menjadi $325 \mathrm{~g} \mathrm{~cm}^{-2}$. Hasil ini menunjukkan bahwa tautan-silang kitosan dengan glutaraldehida telah hampir maksimum dengan 2,0\% (v/v) glutaraldehida. Sedikit hialuronat masih dapat mengisi ruang kosong yang tersisa, tetapi tidak terlalu berpengaruh 
lagi pada kekuatan gel yang dihasilkan. Sebaliknya, penambahan lebih banyak hialuronat justru akan mendesak air keluar dari dalam rongga hidrogel. Hidrogel akan mengerut dan kekuatan gelnya pun menjadi jauh menurun. Penjelasan ini juga dibuktikan dengan kekuatan gel yang jauh menurun $\left(407 \mathrm{~g} \mathrm{~cm}^{-2}\right)$ ketika digunakan 3,0\% (v/v) glutaraldehida tanpa penambahan hialuronat. Nilai ini semakin menurun lagi ketika ditambahkan 0,5 dan $1,0 \%$ (b/v) hialuronat, berturut-turut menjadi 276 dan $244 \mathrm{~g} \mathrm{~cm}^{-2}$.

Jejaring taut-silang yang meluas antara kitosan dan 2,0\% (v/v) glutaraldehida juga dibuktikan dengan semakin sulitnya hidrogel membengkak dan sebaliknya, semakin mudah mengerut jika konsentrasi glutaraldehida ditingkatkan di atas 1,0\% (v/v) (Gambar 5a dan b). Menurut Berger et al. (2004), senyawa penaut-silang akan menurunkan kemampuan hidrogel kitosan untuk membengkak. Tautan-silang yang semakin rapat akan menghalangi cairan memasuki jejaring hidrogel. Sebaliknya, cairan yang telah terperangkap akan mudah terdesak keluar dari matriks gel.

(a)
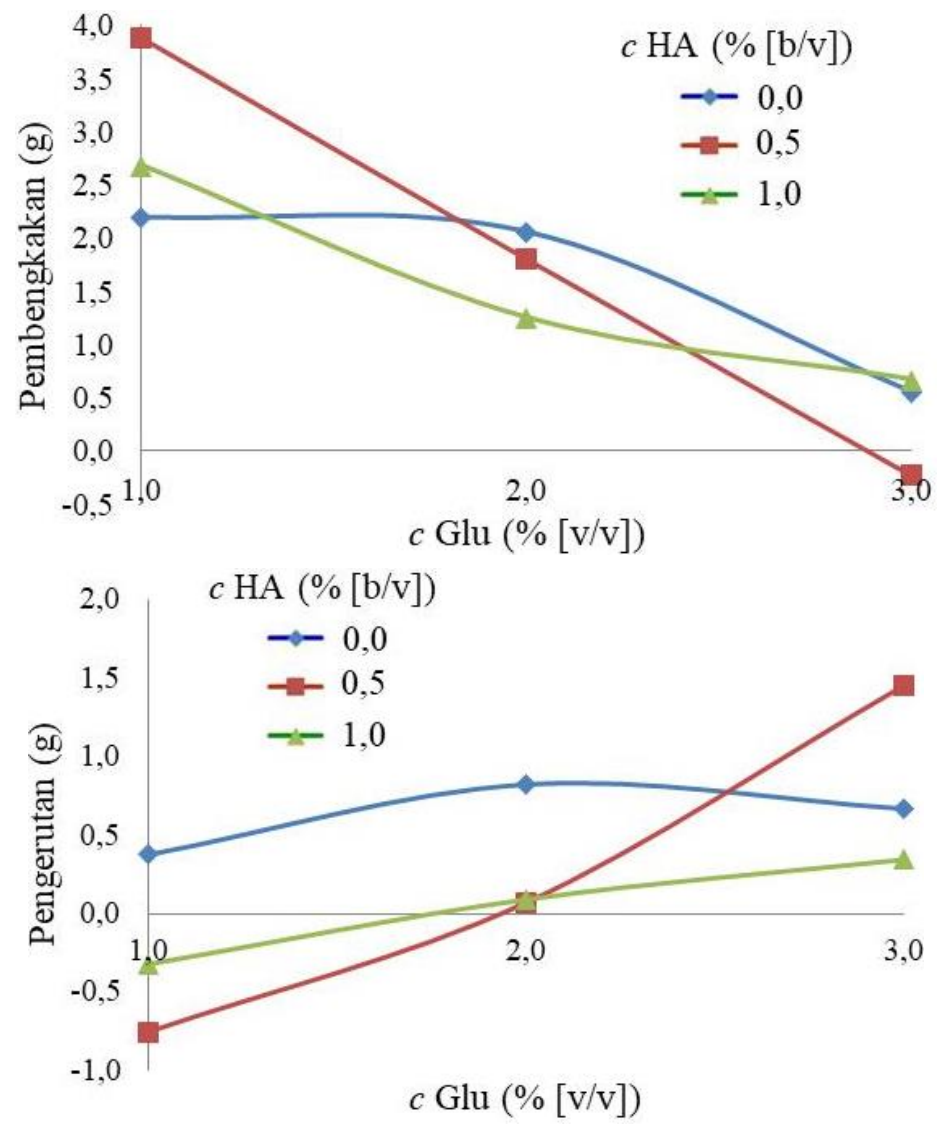

Gambar 5. Pengaruh konsentrasi glutaraldehida dan hialuronat pada pembengkakan (a) dan pengerutan (b) hidrogel kitosan-glutaraldehida-hialuronat.

Hidrogel kitosan dengan 1,0\% (v/v) glutaraldehida tanpa hialuronat membengkak 2,2 g dalam buffer asetat $\mathrm{pH} 4$ setelah 24 jam di suhu kamar. Penambahan 0,5 dan 1,0\% (b/v) hialuronat memperbesar pembengkakan ini berturut-turut menjadi 3,9 dan 2,7 g. 
Hasil ini menunjukkan bahwa hidrogel kitosan dengan 1,0\% (v/v) glutaraldehida masih memiliki banyak ruang kosong. Sekalipun hialuronat telah mengisi sebagian ruang kosong ini, kapasitas pembengkakan tidak menurun. Sebaliknya, penyerapan air dari larutan buffer akan dipercepat oleh adanya ion karboksilat dan gugus hidroksil yang polar pada hialuronat. Hal inilah yang menyebabkan pembengkakan hidrogel naik hampir 2 kali lipat dengan $0,5 \%(b / v)$ hialuronat. Menurunnya pembengkakan pada konsentrasi $1,0 \%(b / v)$ hialuronat menandakan bahwa ruang kosong dalam hidrogel telah terisi penuh atau hampir penuh pada konsentrasi $0,5 \%(\mathrm{~b} / \mathrm{v})$. Oleh karena itu, penambahan lebih banyak hialuronat akan mengurangi ruang kosong yang tersedia untuk menyerap air.

Hidrogel kitosan dengan 2,0\% (v/v) glutaraldehida membengkak 2,1 g, hampir sama dengan $1,0 \%(\mathrm{v} / \mathrm{v})$ glutaraldehida. Namun tautan-silang yang lebih banyak pada konsentrasi glutaraldehida lebih tinggi mengurangi jumlah ruang kosong dalam hidrogel. Oleh sebab itu, penambahan 0,5 dan $1,0 \%(\mathrm{v} / \mathrm{v})$ hialuronat menurunkan pembengkakan berturut-turut menjadi 1,8 dan 1,3 g. Pada penambahan 3,0\% (v/v) glutaraldehida, seperti halnya pada pengukuran kekuatan gel, jejaring taut-silang telah menjadi terlalu rapat, sehingga struktur hidrogel tidak stabil dan mudah mengerut. Hidrogel kitosan hanya menunjukkan pembengkakan sebesar 0,6 g. Setelah ditambahkan hialuronat, nilainya tetap rendah dan tidak diperoleh tren pembengkakan yang beraturan.

Tren data pengerutan cenderung berkebalikan dengan data pembengkakan. Pengerutan terbesar, yaitu 1,5 g yang dialami oleh hidrogel kitosan dengan 3,0\% (v/v) glutaraldehida dan $0,5 \%$ (b/v) hialuronat setelah direndam selama 24 jam dalam buffer fosfat $\mathrm{pH} 7$ pada suhu $10{ }^{\circ} \mathrm{C}$. Buffer fosfat dipakai dalam uji pengerutan karena ukuran molekul fosfat lebih besar daripada asam laktat dan air dalam matriks hidrogel, sehingga mampu mendesak keluar kedua cairan tersebut. Sementara itu, pengerutan terkecil, yaitu $0,8 \mathrm{~g}$, terjadi pada hidrogel kitosan dengan 1,0\% (v/v) glutaraldehida dan 0,5\% (b/v) hialuronat. Nilainya negatif, sebab hidrogel ini justru membengkak selama uji pengerutan.

Gel merupakan suatu semipadatan yang viskoelastis (BeMiller and Huber, 2008). Jadi, suatu hidrogel selain harus kuat dan elastis. Elastisitas hidrogel ditunjukkan oleh titik pecah yang tinggi. Penekan akan dapat berpenetrasi lebih dalam pada hidrogel yang elastis. Merujuk kurva deformasi pada Gambar 6, kekuatan gel ditunjukkan oleh tinggi kurva (BC), sedangkan elastisitasnya ditunjukkan oleh lebar kurva (AC). Hidrogel idealnya memiliki kurva yang tinggi (kokoh) sekaligus lebar (elastis). Hidrogel dengan kurva deformasi yang pendek bersifat labil dan mudah mengerut, sedangkan hidrogel dengan kurva deformasi yang sempit akan kaku dan mudah pecah. Hidrogel dikatakan tegar (rigid) 
jika kokoh, tetapi kaku (kurva tinggi tetapi sempit). Nisbah antara tinggi dan lebar kurva deformasi menentukan ketegaran (rigidity) dari suatu hidrogel.

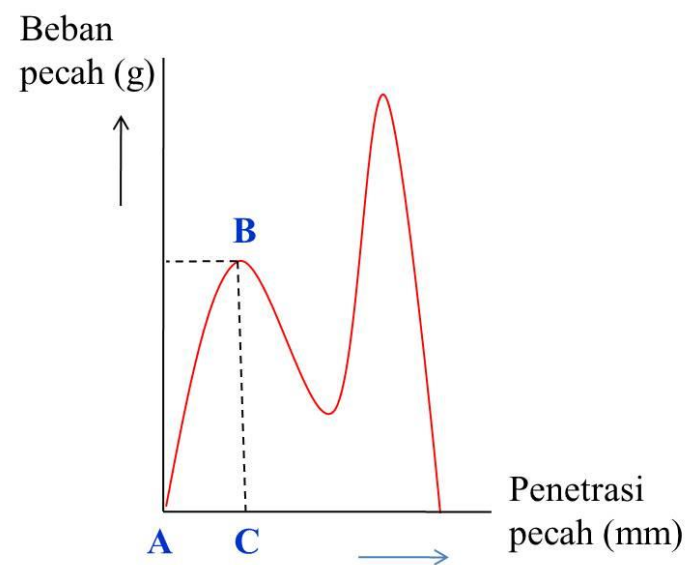

Gambar 6. Bentuk umum kurva deformasi yang diperoleh dengan penganalisis tekstur Stevens LFRA: BC menggambarkan kekuatan gel dan AC adalah titik pecah gel.

Gambar 7(a) dan (b) memperlihatkan pengaruh konsentrasi hialuronat dan glutaraldehida pada titik pecah dan ketegaran hidrogel kitosan-hialuronat. Penambahan $0,5 \%(\mathrm{~b} / \mathrm{v})$ hialuronat dan 2,0\% (v/v) glutaraldehida relatif tidak mengubah titik pecah gel. Nilainya berkisar dari 1,04 hingga 1,31 cm. Akan tetapi, sebagaimana ditunjukkan pada Gambar 7(a), titik pecah ini jauh menurun pada konsentrasi hialuronat dan glutaraldehida lebih tinggi [berturut-turut 1,0\% (b/v) dan 3,0\% (v/v)]. Rentang nilainya dari 0,25 sampai $0,66 \mathrm{~cm}$. Berkurangnya jumlah air yang terperangkap, karena ruang kosong yang sempit oleh banyaknya tautan-silang telah terisi oleh hialuronat yang berjumlah banyak, merupakan faktor penentu menurunnya elastisitas hidrogel.

Gambar 7(b) juga menunjukkan bahwa peningkatan konsentrasi hialuronat ke 1,0\% (b/v) sangat meningkatkan ketegaran gel. Hal ini sejalan dengan penambahan hialuronat yang sangat menurunkan titik pecah (Gambar 7(a)) yang melampaui penurunan kekuatan gel yang diakibatkannya (Gambar 3). Di sisi lain, peningkatan konsentrasi glutaraldehida menjadi 3,0\% (v/v) hanya sedikit meningkatkan ketegaran gel. Tren kekuatan gel (Gambar 3) maupun titik pecah (Gambar 7(a)) sama-sama menunjukkan kenaikan dari konsentrasi 1,0 ke 2,0\% (v/v), lalu menurun ke 3,0\% (v/v). Secara keseluruhan, kenaikan keduanya meningkatkan ketegaran gel. 
(a)

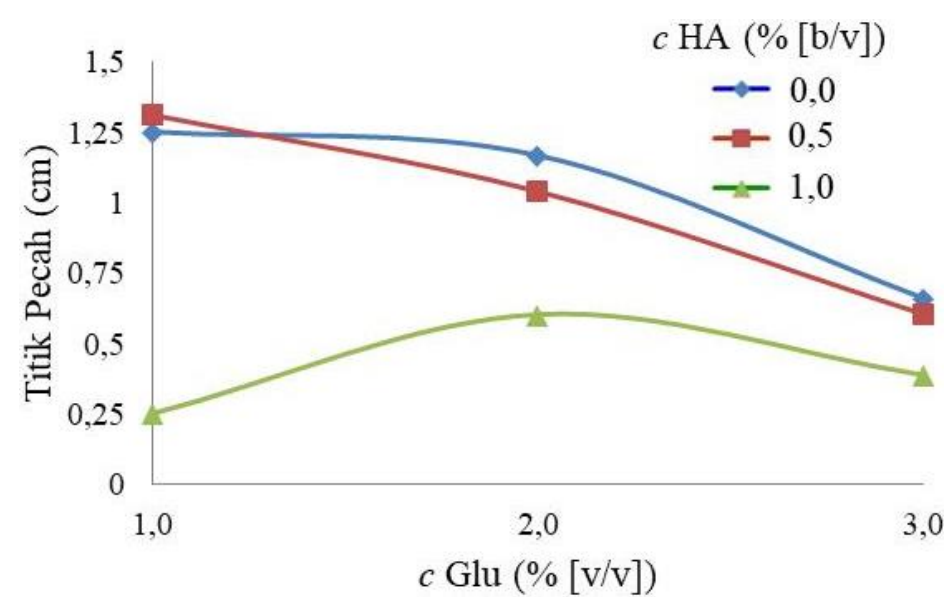

(b)

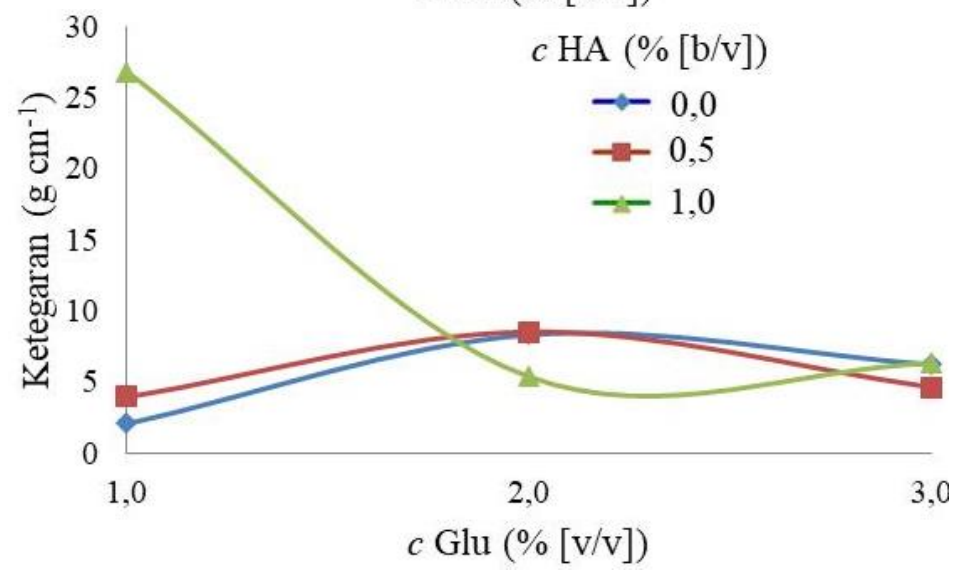

Gambar 7. Pengaruh konsentrasi glutaraldehida dan hialuronat pada titik pecah (a) dan ketegaran (b) hidrogel kitosan-glutaraldehida-hialuronat.

\section{Komposisi Hidrogel dengan Sifat Reologi Optimum}

Analisis data percobaan dengan perangkat lunak Modde $5.0^{\circledR}$ memberikan kombinasi konsentrasi glutaraldehida dan hialuronat optimum, yang diharapkan menghasilkan hidrogel kitosan dengan sifat reologi terbaik. Kekuatan gel maksimum ialah $773,2 \mathrm{~g} \mathrm{~cm}^{-2}$ didapatkan dari $0,3 \%$ (b/v) hialuronat dan 1,8\% (v/v) glutaraldehida. Titik pecah maksimum sebesar 1,332 $\mathrm{cm}$ diperoleh dari $0,1 \%(\mathrm{~b} / \mathrm{v})$ hialuronat dan $1,2 \%(\mathrm{v} / \mathrm{v})$ glutaraldehida. Pembengkakan maksimum mencapai 2,887 g yaitu pada $0,1 \%$ (b/v) hialuronat dan $1,0 \%(\mathrm{v} / \mathrm{v})$ glutaraldehida. Ketegaran gel yang minimum $\left(2,931 \mathrm{~g} \mathrm{~cm}^{-1}\right)$ terjadi pada $0,1 \%(\mathrm{~b} / \mathrm{v})$ hialuronat dan $1,0 \%(\mathrm{v} / \mathrm{v})$ glutaraldehida. Terakhir, pengerutan minimum $(-1,067 \mathrm{~g})$ dihasilkan oleh $1,5 \%(\mathrm{~b} / \mathrm{v})$ hialuronat dan 1,0\% (v/v) glutaraldehida.

Konsentrasi glutaraldehida dan hialuronat optimum yang didapatkan berturut-turut 1,4\% (v/v) dan 0,3\% (b/v). Dibandingkan dengan hidrokoloid lainnya (Tabel 4), konsentrasi hialuronat ialah yang paling rendah. Menurut Lindblad (2003), gel yang baik bersifat elastis, lembut dan mudah membengkak dalam air. Lebih jauh, gel untuk sistem pengantaran obat yang baik harus memiliki kekuatan, titik pecah, dan pembengkakan yang maksimum, serta ketegaran dan pengerutan yang minimum. 
Tabel 4 memperlihatkan bahwa gel kitosan-hialuronat hasil penelitian ini lebih baik dalam hal pengerutan dan titik pecah dibandingkan dengan gel kitosan dengan gom guar, alginat, CMC atau gom xantan. Namun sebaliknya, kekuatan gel dan pembengkakan gel ini paling rendah. Sementara untuk ketegaran, nilainya berada di pertengahan yang lebih baik dibandingkan dengan hidrogel kitosan-alginat dan kitosan-gom xantan, tetapi belum sebaik hidrogel kitosan-gom guar dan kitosan-CMC.

Tabel 4. Komposisi dan sifat reologi optimum gel kitosan-hidrokoloid hasil optimalisasi dengan Modde 5.0 ${ }^{\circledR}$

\begin{tabular}{|c|c|c|c|c|c|}
\hline & Kit-GG & Kit-Alg & Kit-CMC & Kit-GX & Kit-HA \\
\hline [Kitosan] & 2,5 & 2,5 & 2,5 & 2,5 & 2,0 \\
\hline$[\%(\mathrm{~b} / \mathrm{v})]$ & & & & & \\
\hline $\begin{array}{l}\text { [Hidrokoloid] } \\
{[\%(\mathrm{~b} / \mathrm{v})]}\end{array}$ & 0,330 & 0,830 & 0,880 & 1.0 & 0,3 \\
\hline $\begin{array}{l}\text { [Glutaraldehida] } \\
{[\%(\mathrm{v} / \mathrm{v})]}\end{array}$ & 4,86 & 4,00 & 6,00 & 2.40 & 1,4 \\
\hline $\begin{array}{l}\text { Kekuatan } \\
\text { hidrogel }\left(\mathrm{g} \mathrm{cm}^{-2}\right)\end{array}$ & $598,4-731,4$ & 891,3 & 738,9 & 725,1 & 678,4 \\
\hline Titik pecah $(\mathrm{cm})$ & $0,912-1,115$ & 1,025 & 1,068 & 1,083 & 1,294 \\
\hline Ketegaran $\left(\mathrm{g} \mathrm{cm}^{-1}\right)$ & $3,23-3,948$ & 8,518 & 3,510 & 6,110 & 5,033 \\
\hline Pembengkakan (g) & $4,077-4,983$ & 4,069 & 5,337 & 10,264 & 2,634 \\
\hline Pengerutan $(\mathrm{g})$ & $1,167-1,426$ & 1,456 & 1,208 & 1,001 & 0,148 \\
\hline Pustaka & $\begin{array}{l}\text { Sugita et al. } \\
\quad(2006)\end{array}$ & $\begin{array}{l}\text { Sugita et al. } \\
\quad(2007 \mathrm{a})\end{array}$ & $\begin{array}{l}\text { Sugita et al. } \\
\quad(2007 \mathrm{~b})\end{array}$ & $\begin{array}{l}\text { Sugita et al. } \\
\quad(2007 \mathrm{c})\end{array}$ & $\begin{array}{l}\text { Penelitian } \\
\text { ini }\end{array}$ \\
\hline
\end{tabular}

Keterangan: Kit $=$ kitosan, $\mathrm{GG}=$ gom guar, $\mathrm{Alg}=$ alginat, $\mathrm{CMC}=$ karboksimetilselulosa, $\mathrm{GX}=$ gom xantan, $\mathrm{HA}=$ hialuronat.

Hasil validasi menunjukkan bahwa pada kondisi optimum, kekuatan, titik pecah, ketegaran dan pengerutan gel kitosan-hialuronat yang diperoleh lebih kecil dibandingkan dengan hasil optimalisasi Modde $5.0^{\circledR}$. Hal sebaliknya didapatkan untuk pembengkakan (Tabel 5). Nilai pembengkakan dan pengerutan mendekati hasil optimalisasi tetapi nilai kekuatan gel, titik pecah dan pengerutan cukup jauh menyimpang.

Tabel 5. Hasil validasi sifat reologi hidrogel kitosan-hialuronat dengan komposisi optimum hasil optimalisasi dengan Modde $5.0^{\circledR}$

\begin{tabular}{lcc}
\hline \multicolumn{1}{c}{ Respons } & $\begin{array}{c}\text { Hasil Optimalisasi } \\
\text { dengan Modde 5.0 }\end{array}$ & $\begin{array}{c}\text { Hasil Pengukuran } \\
(\boldsymbol{n}=\mathbf{3})\end{array}$ \\
\hline Kekuatan gel $\left(\mathrm{g} \mathrm{cm}^{-2}\right)$ & 678,4 & $191,4 \pm 1,2$ \\
Titik pecah $(\mathrm{cm})$ & 1,294 & $0,890 \pm 0,212$ \\
Ketegaran $\left(\mathrm{g} \mathrm{cm}^{-1}\right)$ & 5,033 & $1,940 \pm 0,458$ \\
Pembengkakan $(\mathrm{g})$ & 2,634 & $2,809 \pm 0,062$ \\
Pengerutan $(\mathrm{g})$ & 0,148 & $0,243 \pm 0,181$ \\
\hline
\end{tabular}


Berdasarkan hasil penelitian ini, penambahan hialuronat pada hidrogel dengan $3,0 \%(\mathrm{v} / \mathrm{v})$ glutaraldehida selalu menghasilkan tren data yang tidak beraturan. Tautsilang yang demikian masif dan tidak menyisakan lagi ruang kosong bagi hialuronat andil dalam hal ini. Konsentrasi 2,0\% (v/v) glutaraldehida masih menghasilkan gel kitosan-hialuronat dengan tren sifat reologi yang baik untuk $0,5 \%(\mathrm{~b} / \mathrm{v})$ hialuronat, tetapi kembali tidak beraturan untuk 1,0\% (b/v) hialuronat. Taut-silang telah cukup banyak terbentuk tetapi masih tersedia ruang kosong bagi $0,5 \%(b / v)$ hialuronat yang tidak mencukupi untuk 1,0\% (b/v) hialuronat. Oleh karena itu, optimalisasi disarankan menggunakan rentang 0,$5 ; 1,0$ dan $1,5 \%(\mathrm{v} / \mathrm{v})$ glutaraldehida untuk 0,5 dan $1,0 \%(\mathrm{~b} / \mathrm{v})$ hialuronat. Jika konsentrasi 2,0\% (v/v) glutaraldehida digunakan maka rentang konsentrasi hialuronat harus diturunkan.

Setiap komposisi hidrogel hanya dibuat 1 kali ulangan dalam penelitian ini, lalu masing-masing diukur 6 kali untuk setiap sifat reologi dan diambil 3 data dengan simpangan baku terkecil. Idealnya, setiap hidrogel juga dibuat dalam beberapa ulangan. Semakin banyak ulangan, hasil validasi diharapkan akan semakin mendekati hasil optimalisasi. Oleh karena itu, penelitian lebih lanjut diusulkan menggunakan 0,$25 ; 0,5 ; 0,75 ; 1,0 ; 1,25$ dan $1,5 \%$ (v/v) glutaraldehida dengan 0,$25 ; 0,50 ; 0,75$ dan $1,0 \%(\mathrm{~b} / \mathrm{v})$ hialuronat, masing-masing sebanyak 3 ulangan gelasi. Setiap pengulangan kemudian diukur 6 kali ulangan untuk setiap sifat reologi dan diambil rerata 3 data dengan simpangan baku terkecil.

\section{KESIMPULAN}

Penambahan hialuronat meningkatkan kekuatan gel, titik pecah dan ketegaran pada konsentrasi glutaraldehida yang rendah tetapi berbalik menurunkannya pada konsentrasi glutaraldehida yang tinggi. Penambahan hialuronat juga meningkatkan pembengkakan dan menurunkan pengerutan kecuali pada konsentrasi glutaraldehida 3,0\% (v/v). Berdasarkan hasil ini, hialuronat diperkirakan mengisi ruang kosong di antara taut-silang imina antara glutaraldehida dan kitosan. Jika konsentrasi glutaraldehida terlalu tinggi, tautan-silang tersebut menjadi sedemikian banyaknya sehingga tidak menyisakan ruang kosong bagi hialuronat. Sebaliknya, hialuronat dan air akan terdesak keluar dari dalam hidrogel.

Analisis data menggunakan perangkat lunak Modde $5^{\circledR}$ menunjukkan bahwa komposisi optimum diperoleh pada konsentrasi kitosan 2,0\% (b/v), hialuronat $0,3 \%(\mathrm{v} / \mathrm{v})$ dan glutaraldehida $1,4 \%(\mathrm{v} / \mathrm{v})$ yang menghasilkan kekuatan gel, titik pecah, ketegaran, pembengkakan dan pengerutan berturut-turut sebesar $678,4 \mathrm{~g} \mathrm{~cm}^{-2} ; 1,294 \mathrm{~cm} ; 5,033 \mathrm{~g}$ 
$\mathrm{cm}^{-1} ; 2,634 \mathrm{~g}$ dan 0,148 g. Namun penerapan komposisi optimum tersebut dalam eksperimen ternyata belum menghasilkan sifat reologi yang sesuai dengan prediksi. Masih diperlukan optimalisasi lanjutan dengan menurunkan konsentrasi glutaraldehida di bawah 2,0\% (v/v), mempersempit selang konsentrasi glutaraldehida dan hialuronat yang digunakan serta membuat setiap komposisi hidrogel dalam beberapa ulangan.

\section{DAFTAR PUSTAKA}

Ahmadi, F., Oveisi, Z., Samani, S.M., and Amoozgar, Z., 2015. Chitosan Based Hydrogels: Characteristics and Pharmaceutical Applications. Research in Pharmaceutical Sciences 10(1), 1-16.

Argin-Soysal, S., Kofinas, P., and Martin, L., 2009. Effect of Complexation Conditions on Xanthan-Chitosan Polyelectrolyte Complex Gels. Food Hydrocolloids 23(1), 202 209.

BeMiller, J.N., and Huber, K.C., 2008. Carbohydrates. In: Damodaran, S., editor. Fennema's Food Chemistry, fourth ed. CRC Press, Boca Raton, 113.

Beppu, M.M., Vieira, R.S., Aimoli, C.G., and Santana, C.C., 2007. Crosslinking of Chitosan Membranes using Glutaraldehyde: Effect on Ion Permeability and Water Absorption. Journal of Membrane Science 301(1-2), 126-130.

Berger, J., Reist, M., Mayer, J.M., Felt, O., Peppas, N.A., and Gurny, R., 2004. Structure and Interactions in Covalently and Ionically Crosslinked Chitosan Hydrogels for Biomedical Applications. European Journal of Pharmaceutics and Biopharmaceutics 57(1), 19-34.

Bourne, M., 2002. Food Texture and Viscosity: Concept and Measurement, second ed. Academic Press, San Diego, 198-199.

Buriuli, M., and Verma, D., 2017. Polyelectrolyte Complexes (PECs) for Biomedical Applications. In: Tripathi, A., Melo, J.S. , editor. Advances in Biomaterials for Biomedical Applications. Advanced Structure Materials Series Volume 66. Springer Singapore, Singapura, 48.

Cleland, R.L., 1983. Viscometric Study of The Proteoglycan-Hyaluronate (2:1) "Dimer": Minimum Hyaluronate Chain Length. Biopolymers 22(12), 2501-2506.

Coimbra, P., Alves, P., Valente, T.A.M., Santos, R., Correia, I.J., and Ferreira, P., 2011. Sodium Hyaluronate/Chitosan Polyelectrolyte Complex Scaffolds for Dental Pulp Regeneration: Synthesis and Characterization. International Journal of Biological Macromolecules 49(4), 573-579.

Duarte, A.R.C., Mano, J.F., and Reis, R.L., 2009. Preparation of Chitosan Scaffolds Loaded with Dexamethasone for Tissue Engineering Applications Using Supercritical Fluid Technology. European Polymer Journal 45(1), 141-148.

Holmes, C.A., and Tabrizian, M., 2013. Substrate-Mediated Gene Delivery from GlycolChitosan/Hyaluronic Acid Polyelectrolyte Multilayer Films. Applied Material Interfaces 5(3), 524-531.

Kaderli, S., Boulocher, C., Pillet, E., Watrelot-Virieux, D., Rougemont, A.L., Roger, T., Viguier, E., Gurny, R., Scapozza, L., and Jordan, O., 2015. A Novel Biocompatible 
Hyaluronic Acid-Chitosan Hybrid Hydrogel for Osteoarthrosis Therapy. International Journal of Pharmaceutics 483(1-2), 158-168.

Khan, T.A., Peh, K.K., and Ching, H.S., 2002. Reporting Degree of Deacetylation Values of Chitosan: The Influence of Analytical Methods. Journal of Pharmacy and Pharmaceutical Sciences 5(3), 205-212.

Kim, S.J., Yoon, S.G., Lee, K.B., Park, Y.D., and Kim, S.I., 2003. Electrical Sensitive Behavior of A Polyelectrolyte Complex Composed of Chitosan/Hyaluronic Acid. Solid State Ionics 164(3-4), 199-204.

Kuo, J.W., 2006. Practical Aspects of Hyaluronan Based Medical Products. CRC Press, Boca Raton.

Lindblad, M.S., 2003. Strategies for Building Polymers from Renewable Source: Using Prepolymers from Steam Treatment of Wood and Monomers from Fermentation of Agricultural Products, thesis. KTH Fibre and Polymer Technology, Royal Institute of Technology, Stockholm.

Mak, A., and Sun, S., 2008. Intelligent Chitosan-Based Hydrogels as Multifunctional Materials. In: Shahinpoor, M., Schnieder, H.J., editor. Intelligent Materials. Royal Society of Chemistry, Cambridge, 47-461.

Manna, U., Bharani, S., and Patil, S., 2009. Layer-by-Layer Self-Assembly of Modified Hyaluronic Acid/Chitosan Based on Hydrogen Bonding. Biomacromolecules 10(9), 2632-2639.

Monteiro Jr, O.A.C., and Airoldi, C., 1999. Some Studies of Crosslinking ChitosanGlutaraldehyde Interaction in A Homogenous System. International Journal of Biological Macromolecules 26(2-3), 119-128.

Montembault, A., Viton, C., and Domard, A., 2005. Physico-chemical Studies of The Gelation of Chitosan in a Hydroalcoholic Medium. Biomaterials 26(8), 933-943.

Mráček, A., Varhaniková, J., Lehocký, M., Gřundělová, L., Pokopcová, A., and Velebný, V., 2008. The Influence of Hofmeister Series Ions on Hyaluronan Swelling and Viscosity. Molecules 13(5), 1025-1034.

Nishinari, K., and Takahashi, K., 2003. Interaction in Polysaccharide S olutions and Gels. Current Opinion in Colloid and Interface Science 8(4-5), 396-400.

Shang, J., Shao, Z., and Chen, X. 2008a. Electrical Behavior of A Natural Polyelectrolyte Hydrogel: Chitosan/carboxy-methylcellulose Hydrogel. Biomacromolecules 9(4), 1208-1213.

Shang, J., Shao, Z., and Chen, X. 2008b. Chitosan-Based Electroactive Hydrogel. Polymer 49(25), 5520-5525.

Sugita, P., Sjachriza, A., and Lestari, S.I. 2006. Sintesis dan Optimalisasi Gel KitosanGom Guar. Jurnal Natur Indonesia 9, 32-36.

Sugita, P., Sjachriza, A., and Wahyono, D. 2007a. Sintesis dan Optimalisasi Gel KitosanAlginat. Jurnal Sains dan Teknologi Indonesia 9(1), 22-26.

Sugita, P., Sjachriza, A., and Rachmanita, 2007b. Sintesis dan Optimalisasi Gel KitosanKarboksimetil Selulosa. ALCHEMY: Jurnal Penelitian Kimia 6(1), 57-62. 
Sugita, P., Sjachriza, A., and Utomo, D.W. 2007c. Optimization synthesis chitosanxanthan gum gel for metal adsorption. In: Prosiding $1^{\text {st }}$ International Conference on Chemical Sciences. MAT/33-4. 25-26 Mei 2007, Yogyakarta.

Tahtat, D., Mahlous, M., Benamer, S., Khodja, A.N., Oussedik-Oumehdi, H., and LarabaDjebari, F., 2013. Oral Delivery of Insulin from Alginate/Chitosan Crosslinked by Glutaraldehyde. International Journal of Biological Macromolecules 58, 160-168.

Tarbojevich, M., and Cosani, A., 1997. Molecular Weight Determination of Chitin and Chitosan. In: Muzarelli, R.A.A., Peter, M.G., editor. Chitin Handbook. European Chitin Society, Grotammare, 85-108.

Tomihata, K., and Ikada, Y., 1997. Crosslinking of Hyaluronate with Glutaraldehyde. Journal of Polymer Science 35(16), 3553-3559.

Wang, T., Turhan, M., and Gunasekaram, S., 2004. Selected Properties of pHSensitive, Biodegradable Chitosan-Poly(vinyl alcohol) Hydrogel. Polymer International 53 (7), 911-918. 